\title{
Нлле НОХАННЕС
}

\section{ФЛОТАЦИЯ НИОБИЯ ИЗ ТАРТРАТНЫХ, ОКСАЛАТНЫХ И ПЕРОКСИДНЫХ РАСТВОРОВ}

\author{
(Представил Н. Клесмент)
}

Сущность ионной флотации состоит в связывании находящегося в растворе иона с противоположно заряженным поверхностно-активным ионом в малорастворимое соединение и в извлечении последнего в пену. О состоянии ниобия в водных растворах имеется мало сведений. Известно $[1,2]$, что в связи с большим зарядом и малым радиусом $(0,69 \AA)$ ниобий $(\mathrm{V})$ в водных растворах в виде простых ионов почти не существует. Его характерным свойством является склонность к образованию различных гидролизованных полимерных форм и комплексных ионов. Большинство из них мало изучено. Наиболее распространенными комплексообразователями для ниобия являются фтористый водород, винная кислота, щавелевая кислота и перекись водорода. Цель настоящей работы - изучить флотируемость ниобия из тартрат-, оксалат- и пероксидсодержащих растворов в широком диапазоне рН среды.

Среди работ, посвященных ионной флотации и родственным ей процессам [3], имеется лишь одна $\left.{ }^{4}\right]$, где исследовалась флотируемость коллоидной гидроокиси ниобия из $7,3 \cdot 10^{-3} \mathrm{M}$ раствора хлорокиси ниобия при величине $\mathrm{pH} \mathrm{1,62.} \mathrm{В} \mathrm{качестве} \mathrm{собирателя} \mathrm{применялся} \mathrm{желатин.}$ Показана еще возможность эмульсионного извлечения коллоидной гидроокиси ниобия из его $1 \cdot 10^{-3} \mathrm{M}$ растворов $2-5 \mathrm{M}$ растворами карбоновых кислот в бензоле с максимумом извлечения ниобия при $\mathrm{pH}$ осаждения его гидроокиси [5,6].

\section{Экспериментальная часть}

Исходные растворы готовились сплавлением пятиокиси ниобия с 10 -кратным количеством пиросульфата калия и растворением сплава в растворе винной и щавелевой кислот или в смеси серной кислоты и перекиси водорода. Концентрация ниобия во флотируемых растворах составляла $5 \cdot 10^{-4}$-атом $/ \Omega$, концентрация винной, щавелевой и серной кислот перед регулированием величины $\mathrm{pH}$ среды - 0,5\% и перекиси водорода - $1,5 \%$. Величина $\mathrm{pH}$ растворов регулировалась в пределах $1-12$ прибавлением серной кислоты или гидроокиси натрия. В качестве собирателей применялись $0,1 \mathrm{M}$ растворы анионного реагента додеканата натрия и катионного реагента гидрохлорида додециламина. Чтобы обна́ружить изменение величины заряда флотируемых соединений ниобия, установить границы его максимального извлечения и расход собирателя, флотация проводилась в условиях недостатка и явного 
0

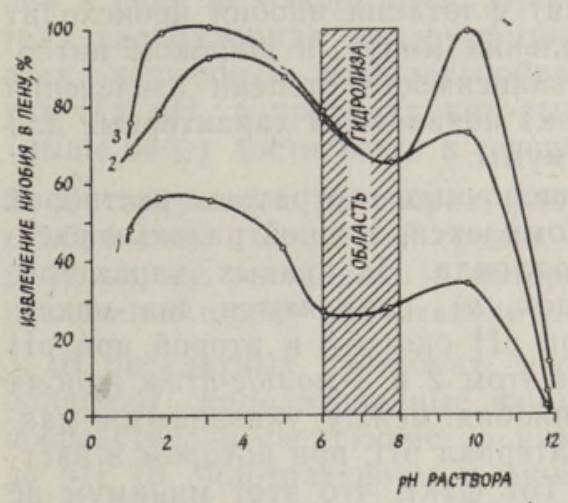

b

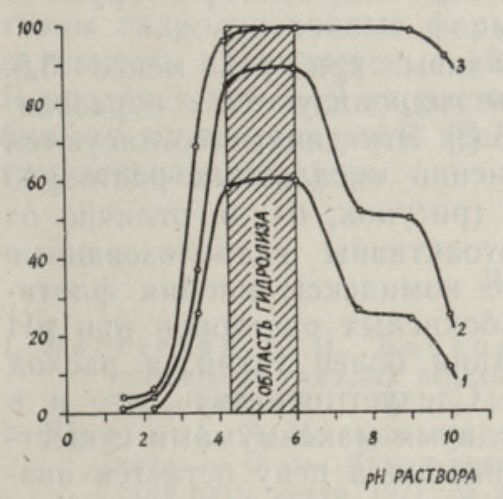

$\delta$

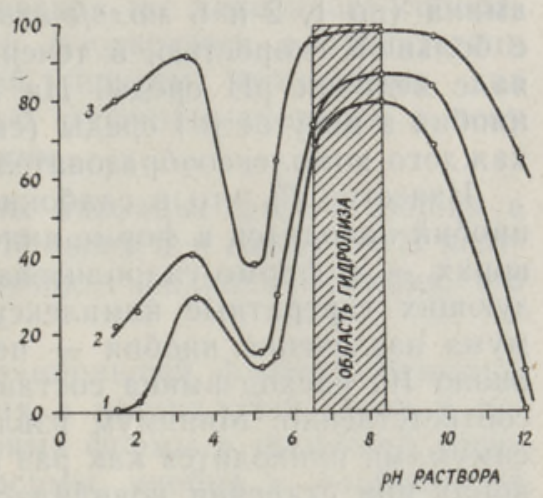

Влияние $\mathrm{pH}$ на извлечение ниобия в пену из трех растворов: $a$ - из тартратного $(0,5 \%$ винной кислоты), б оксалатного $(0,5 \%$ щавелевой кислоты), в - пероксидного $(1,5 \%$ перекиси водорода) при добавлении гидрохлорида додециламина в количестве $5 \cdot 10^{-4}$ (кривые 1), 1.10-3 (кривые 2) и $3 \cdot 10^{-3}$ моль/л (кривые 3).

избытка собирателя. Степень извлечения ниобия в пену определялась по его содержаниям в исходном и в остаточном после флотации раствоpax спектрофотометрически с 1-(2-пиридилазо)резорцином [ $\left.{ }^{7}\right]$. Флотационная установка описана в [ $\left.{ }^{8}\right]$.

Флотация проводилась в день приготовления исходных растворов и регулирования $\mathrm{pH}$ среды. Все исходные для флотации растворы былі прозрачные. Через двое суток в тартратных и оксалатных растворах с pH 6,0-8,5 появилась слабая муть, а более кислые и более щелочные растворы оставались прозрачными в течение месяцев. Из пероксидных же растворов осадок выпал при более низких значениях рН среды через двое суток в пределах $\mathrm{pH} 4,2-5,2$, а через две недели уже и при pH 6,0. Можно полагать, что в этих пределах $\mathrm{pH}$ раствора образуются гидролизованные формы ниобия, следовательно, изменяются и его флотационные свойства.

Опытами установлено, что из тартратных, оксалатных и пероксидных растворов с применением анионного собирателя додеканата натрия (по 2 и 4 моль/г-атом ниобия) ниобий не извлекался в пену по всему исследованному диапазону величин $\mathrm{pH}$ среды. Следовательно, в отличие от коллоидной гидроокиси ниобия без комплексообразователей, флотируемой желатином [4] и эмульгируемой карбоновыми кислотами [5,6], в тартратных, оксалатных и пероксидных растворах катионных флотируемых форм ниобия не существует. 
В случае применения катионного собирателя гидрохлорида додециламина (по 1, 2 и 6 моль/2-атом ниобия) флотация ниобия происходит с большой скоростью, в течение нескольких минут, в широком интервале величин рН среды. На кривых зависимости степени извлечения ниобия в пену от рН среды (см. рисунок) появляются характерные для каждого комплексообразователя максимумы.

Известно [9], что в слабокислых и щелочных тартратных растворах ниобий находится в форме анионного комплекса, а в нейтральных растворах - в форме гидролизованного коллоида. На кривых, характеризующих тартратные комплексы (рисунок, $a$ ), появляются два максимума извлечения ниобия - первый при $\mathrm{pH}$ около 3 и второй при $\mathrm{pH}$ около 10 ; расход амина составляет при этом 2 и 3 моль/ح-атом ниобия соответственно. Минимум извлечения ниобия между указанными максимумами приходится как раз на тот интервал $\mathrm{pH}$, при котором в раст. ворах при старении появлялась муть. Тот факт, что этот минимум не исчезает и при явном избытке амина (рисунок, $a$; кривая 3 ), свидетельствует о том, что наряду с анионными гидролизованными коллои ными формами в растворе существуют и незаряженные нефлотируемые формы ниобия.

Оксалатные комплексы ниобия устойчивы при $\mathrm{pH}$ менее 5,5. В растворах с рН выше 5,8 эти комплексы гидролизуются с образованием золя, коагулирующегося при $\mathrm{pH} 7-8\left[{ }^{9}\right]$. Эти данные согласуются с приведенными выше данными о помутнении оксалатных растворов при старении. В оксалатных растворах (рисунок, б), в отличие от тартратных (рисунок, $a$ ), наиболее флотоактивны гидролизованные формы ниобия ( $\mathrm{pH} 6,5-8,5)$. Оксалатные комплексы ниобия флотируются, аналогично тартратным, и из слабокислых растворов при рН около 3 , но интервал их активной флотации более узкий, а расход амина более высокий, чем у тартратных. Следует отметить, что и в оксалатных растворах между указанными двумя максимумами существует интервал $\mathrm{pH}$, в котором извлечение ниобия в пену остается низким и при явном избытке амина.

В пероксидных растворах ниобия (рисунок, в) при старении выпадает осадок, т. е. гидролиз происходит в более кислой области (pH 4,2-6,0), чем в тартратных и оксалатных растворах. В той же области рН находится максимум извлечения ниобия в пену при недостатке собирателя (рисунок, в; кривые 1,2 ). При избытке же собирателя (там же; кривая 3) успешно флотируются и растворимые анионные соединения ниобия из щелочных растворов, а область максимального извлечения ниобия распространяется уже до $\mathrm{pH} 4-9$. Расход амина для флотации гидролизованных и анионных форм составляет 2 и 4 моль/г-атом ниобия соответственно. В отличие от растворов, содержащих оксикислоты, в пероксидных растворах при избытке амина не наблюдается ухудшения флотируемости ниобия на переходном участке из одной области его максимального извлечения в другую. Процесс флотации идет активно и плавно в широком интервале $\mathrm{pH}$ среды.

\section{Выводы}

Исследованием флотируемости ниобия из его $5 \cdot 10^{-4} \mathrm{M}$ тартратных, оксалатных и пероксидных растворов в диапазоне $\mathrm{pH}$ среды $1-12$ установлено:

1. В случае применения анионного собирателя додеканата натрия нио- 
бий в пену не извлекается. При использовании же катионного собирателя гидрохлорида додециламина ниобий флотируется в присутствии всех изученных комплексообразователей, причем существуют два участка $\mathrm{pH}$, в пределах которых высокая степень извлечения в пену (выше 90\%) достигается в течение $1-2$ мин.

2. В тартратных растворах флотоактивны анионные формы ниобия в слабокислой и щелочной средах - при рН около 3 и около 10. В нейтральных же растворах, в которых происходит гидролиз ниобия, его извлечение в пену значительно снижается.

3. В оксалатных растворах, наоборот, наибольшей флотоактивностью обладают гидролизованные формы ниобия в нейтральной среде и непосредственно следующие за ними анионные формы в щелочной среде до $\mathrm{pH}$ 10. Флотоактивны и анионные формы ниобия в слабокислой среде - при рН около 3. Между этими двумя участками рН извлечение ниобия в пену резко снижается.

4. В пероксидных растворах, как и в оксалатных, наиболее флотоактивны гидролизованные формы ниобия, только пределы рН, где эта активность проявляется, сдвинуты в более кислую область (рH 4-6). В пределах рН 7-9 из раствора флотируются и анионные формы ниобия, но амина при этом требуется вдвое больше, чем при флотацич гидролизованных форм.

\section{Л ИТЕ Р АТ У Р А}

1. Алексеева И. И., Бобкова М. В., Чернышова Л. М. Многоядерные соединения тяжелых переходных металлов. - Изв. ВУЗов. Химия и хим. технол., 1980, XXIII, № 1 , с. $17-20$.

2. Шитин А. П. Исследование свойств фосфорнокислых растворов ниобия и тантала. - В кн.: Химия редких элементов. Тр. Ин-та химии АН СССР, Уральский науч. центр, 1971 , № 23, с. $68-73$.

3. Гольман А. М. Вопросы теории ионной флотации. - В кн.: Современное состояние и перспективы развития теории флотации. М., 1979, с. $147-171$.

4. Скрылев Л. Д., Са вельев В. Н., Мокрушин С. Г. Выделение коллондной гидроокиси ниобия из солянокислых растворов методом флотации. - Изв. ВУЗов. Химия и хим. технол., 1967, Х, № 5 , с. $525-529$.

5. Скрылев Л. Д., Петренко Ж. В., Михайличенко Н. И., Мохосоев М. В. Эмульсионное извлечение коллоидных гидроокисей ниобия и тантала. - Изв. ВУЗов. Химия и хим. технол., 1974, XVII, № 9, с. 1338 - 1341.

6. Михайличенко Н. И., Скрылев Л. Д., Петренко Ж. В., Мохосое в М. В. Впияние некоторых факторов на эмульсионное извлечение гидроокисей ниобия и тантала. - Изв. ВУЗов. Химия и хим. технол., 1978, XXI, № 1 , c. $14-18$.

7. Ги бало И. М. Аналитическая химия ниобия и тантала. М., 1967, с. $85-87$,

8. Иоханнес И. Селективная флотащия галлия из цинксодержащих растворов. Изв. АН ЭССР. Химия, 1980 , т. 29, № 3, с. 224-226.

9. Гор о ще к о Я. Г. Химия ниобия и тантала. Кнев, 1965 , с. 387.
Ннститут химии
Академии наук Эстонской ССР
Поступила в редакцию 26/VI 1980 
Ille JOHANNES

\section{NIOOBIUMI FLOTEERIMINE TARTRAATSEIST, OKSALAATSEIST JA PEROKSIIDSEIST LAHUSTEST}

On uuritud nioobium(V) floteeritavust tema $5 \cdot 10^{-4} \mathrm{M}$ tartraatseist, oksalaatseist ia peroksiidseist lahustest $\mathrm{pH}$ vahemikus $1-12$. Kui kogujana kasutada naatriumdodekanaati, siis nioobium uuritud tingimustel ei floteeru. Dodetsüülamiinvesinikkloriidi kasutamisel kogujana eraldub nioobium vahtu kõigi uuritud kompleksimoodustajate puhul 1-2 minuti jooksul, kusjuures floteeritavuse sōltuvus $\mathrm{pH}$ väärtusest on iga kompleksimoodustaja puhul erinev.

Ille JOHANNES

\section{FLOTATION OF NIOBIUM FROM TARTRATE, OXALATE AND PEROXIDE SOLUTIONS}

Niobium(V) floatability from its $5 \cdot 10^{-4} \mathrm{M}$ tartrate, oxalate and peroxide solutions was investigated in the $\mathrm{pH}$ range of $1-12$. It was established that when using sodium dodecanate as collector, niobium was not floatable under the investigated conditions. By using dodecylamine hydrochloride as collector, it was observed that niobium floated within $1-2 \mathrm{~min}$, whereas $\mathrm{pH}$-value dependence of floatability was different in case of each complexing agent. 